\title{
Variations in the Shades of Contemporary Dental Ceramics: An In Vitro Analysis
}

\author{
Syed Rashid Habib ${ }^{1, *}\left(\mathbb{D}\right.$, Abdulaziz Saud Al Rashoud ${ }^{2}$, Turki Ali Safhi ${ }^{2}$, Abdulrahman Hamad Almajed ${ }^{2}$, \\ Hamad Ali Alnafisah ${ }^{2}$, Salwa Omar Bajunaid ${ }^{1}$, Abdulaziz S. Alqahtani ${ }^{1}$ and Mohammed Alqahtani ${ }^{1}$ \\ 1 Department of Prosthetic Dental Sciences, College of Dentistry, King Saud University, Riyadh 11545, \\ Saudi Arabia; bajunaid@ksu.edu.sa (S.O.B.); Absalqahtani@ksu.edu.sa (A.S.A.); \\ moqahtani@ksu.edu.sa (M.A.) \\ 2 Interns, College of Dentistry, King Saud University, Riyadh 11545, Saudi Arabia; \\ azizalrashoud@gmail.com (A.S.A.R.); xizturki@gmail.com (T.A.S.); a-almajd@hotmail.com (A.H.A.); \\ Hamad.alnafisah@gmail.com (H.A.A.) \\ * Correspondence: syhabib@ksu.edu.sa; Tel.: +966-534750834
}

check for updates

Citation: Habib, S.R.; Rashoud, A.S.A.; Safhi, T.A.; Almajed, A.H.; Alnafisah, H.A.; Bajunaid, S.O.; Alqahtani, A.S.; Alqahtani, M. Variations in the Shades of Contemporary Dental Ceramics: An In Vitro Analysis. Crystals 2021, 11, 1288. https://doi.org/10.3390/ cryst11111288

Academic Editors:

Anastasia Katsavochristou,

Dimitrios Koumoulis and Michele Iafisco

Received: 9 September 2021 Accepted: 21 October 2021 Published: 24 October 2021

Publisher's Note: MDPI stays neutral with regard to jurisdictional claims in published maps and institutional affiliations.

Copyright: (c) 2021 by the authors. Licensee MDPI, Basel, Switzerland. This article is an open access article distributed under the terms and conditions of the Creative Commons Attribution (CC BY) license (https:/ / creativecommons.org/licenses/by/ $4.0 /)$.

\begin{abstract}
Background: To identify and compare the shade variations of various commonly used esthetic dental ceramics by calculating their total-color-difference $(\Delta \mathrm{E})$ and translucency parameter (TP) using a spectrophotometer. Methods: In total, 165 disc specimens from three shades (A1, B1, and C1) of five ceramic materials ( $N=55 /$ shade; $n=11 /$ ceramic material group) were prepared (Metal-ceramic (MC), IPS e.max press (Emax-P), IPS e.max layer (Emax-L), Layered Zirconia (Zr-L) and Monolithic zirconia (Zr-M)). With a spectrophotometer, the $\mathrm{L}^{*} \mathrm{a}^{*} \mathrm{~b}^{*}$ values were obtained. Total color differences $\left(\Delta \mathrm{E}=\left[\left(\Delta \mathrm{L}^{*}\right) 2+\left(\Delta \mathrm{a}^{*}\right) 2+\left(\Delta \mathrm{b}^{*}\right) 2\right]^{1 / 2}\right)$ and translucency parameter $\left(T P=\left[\left(L^{*} B-L^{*} W\right)^{2}+\left(a^{*} B-a^{*} W\right)^{2}+\left(b^{*} B-b^{*} W\right)^{2}\right]^{1 / 2}\right)$ were calculated. The statistical tests included ANOVA and Post hoc Tukey's analysis $(p<0.05)$. Results: Significant differences $(p=0.000)$ were found between the groups for $\Delta \mathrm{E}$. Highest $\Delta \mathrm{E}$ (A1) were found for $\mathrm{Zr}-\mathrm{L}(80.18 \pm 20)$ and lowest for $\mathrm{Zr}-\mathrm{M}(62.97 \pm 1.28)$. For $\mathrm{B} 1$, highest $\Delta \mathrm{E}$ values were noted for $\mathrm{MC}(76.85+0.78)$ and lowest for the Emax-L $(62.13 \pm 1.49)$. For $\mathrm{C} 1$, highest $\Delta \mathrm{E}$ values were found for the $\mathrm{MC}$ group $(73.96 \pm 0$ 67) and lowest for Emax-P (55.09 \pm 1.76$)$. Translucency variations between tested ceramics were revealed $(p<0.05)$. Highest TP values (A1) were found for Emax-L $(2.99 \pm 1.64)$ and lowest for $\mathrm{Zr}-\mathrm{L}(0.35 \pm 0.16)$. For B1, highest TP values were noted for Emax-P (3.50 \pm 1.74$)$ and lowest for $\mathrm{MC}(0.57 \pm 0.40)$. For $\mathrm{C} 1$, highest TP values were found for Emax-P $(4.46 \pm 2.42)$ and lowest for $\mathrm{MC}(0.58 \pm 048)$. Conclusions: Significant differences in $\Delta \mathrm{E}$ and $\mathrm{TP}$ were found for tested ceramic groups. The color differences of the tested materials varied according to clinical acceptability, even with the selection of same color/shade. The color/shades of the various dental ceramics do not match with the vita shade guide tabs, to which they are compared most often. Shade differences are present between different lots of ceramic materials from the same or different brands.
\end{abstract}

Keywords: dental ceramics; dental shade; translucency parameter; color difference; delta E; ceramics

\section{Introduction}

Dental ceramics are inert, highly biocompatible, and are considered the materials of choice for indirect restorations of the anterior teeth [1]. In addition, and most importantly when esthetics is the primary goal to achieve, dental ceramics become the material to be selected, because of their high similarity in color to the natural dentition [2]. Dentists and the dental ceramists have always been trying to produce ceramic restorations with esthetically pleasing shape as well as most importantly a shade that matches with the adjacent teeth [3]. The correct shade match is challenging as it requires not only the 'color matching skills' from the dentists but also to communicate about the shade correctly to the technician and lastly the understanding of the technician about the correct shade and his skills in reproducing the same desired shade in the artificial teeth. All these steps 
are critically vital to meet patient's expectations and high precision is expected from the dentists and the dental technicians $[4,5]$.

Understanding the scientific basis of tooth shade matching, and its communication to the dental technicians, is required from the dentists, in order to communicate the information to the technicians accurately [6,7]. Conventionally and most commonly the shade matching of the existing adjacent teeth with the commercially available shade guide tabs 'considered as the gold standard for the shade matching' are performed via visual comparison [7]. The visual selection involves the dentists, their assistants or staff, and finally the patient and their attendants. Though this technique provides a quick, fast, and cost effective solution to the color matching step, this visual selection is subjective, requires skills, and varies among individuals. In addition, due to the polychromatic structure of the natural teeth and limitations of the visual shade matching with tabs, a permanent and viable solution to address the wide color range present in the natural teeth cannot be provided $[8,9]$.

Recently, some newly developed dental ceramics for the restoration of anterior teeth have shown promising results in terms of composition, improved physical and mechanical properties, and esthetic properties of shade and translucency [10]. The high variety of commercially available dental ceramics poses a new challenge for the dentists and dental technicians from the shade matching point of view [1]. These ceramics with a lower biomimetic potential, due to the difference in their crystalline structure as compared to natural teeth and because of the difference in the translucency, opacity, effects, absence and presence of fluorescence, may not provide the optimal esthetic solution $[1,2,10]$. These physical properties make the shade matching between the natural dentition to the artificial dental ceramics difficult, if not impossible, to obtain [6].

The most common color parameters that help in choosing the dental ceramics from shade perspective and for the evaluation and comparison of color differences are the delta $\mathrm{E}(\Delta \mathrm{E})$ and translucency parameter (TP) [11,12]. $\Delta \mathrm{E}$ which is also termed as the totalcolor-difference, is obtained from calculation based on ' $\mathrm{L}^{*}, \mathrm{a}^{*}, \mathrm{~b}^{* \prime}$ values. The advantage of $\Delta \mathrm{E}$ is that it quantifies the combined shade differences between the various esthetic materials with a numerical number, and makes the comparisons between these materials simple, convenient, and easy $[13,14]$. Further to $\Delta \mathrm{E}$, the dental ceramics' translucency is also considered as an important clinical parameter for classifying the esthetic materials into esthetic or non-esthetic and is obtained by calculating the difference between the $L^{*} a^{*} b^{*}$ values of the test materials over white and black background at a standardized thickness termed as TP. The TP provides a value corresponding directly to human visual perception of translucency. Different all-ceramic systems have different TPs [15,16].

Thus, the objective of the present in vitro study was to identify, investigate, and compare shade variations of most commonly used and latest esthetic dental ceramics by calculating their $\triangle E$ and TP using $\mathrm{L}^{*} \mathrm{a}^{*} \mathrm{~b}^{*}$ values obtained from a spectrophotometer. The null hypothesis was that the commonly used materials will have no color difference and will exhibit no difference statistically in the shade between the tested ceramic restorative materials.

\section{Materials and Methods}

Before initiation of the study, ethical clearance was obtained from the ethics committee at the college of dentistry research center (CDRC), King Saud University (Registration \# IR 0359). The study was conducted from September 2020 to March 2021 at the department of prosthodontics and CDRC, college of dentistry, King Saud University, Riyadh, KSA.

\subsection{Selection of Materials and Sample Size Calculation}

Five commonly used restorative materials (Metal-ceramic (MC), IPS e.max press (Emax-P), IPS e.max layer (Emax-L), Layered Zirconia (Zr-L) and Monolithic zirconia $(\mathrm{Zr}-\mathrm{M})$ ) were chosen based on their high demand/availability in the commercial market and the ease of preparation. Three shades from every material were selected A1, B1, and 
C1. Details of the materials used in the study are presented in Table 1. The sample size per group was calculated to be 11 with a total sample size of 55 for each shade, using G-power software (G*Power 3.1.9.7, Germany) [17] with effect size of 0.5 , power 0.82 , and $\alpha 0.05$.

Table 1. Details of the materials used in the research study.

\begin{tabular}{|c|c|c|c|c|c|}
\hline S. No. & Group & Material & Trade Name & Manufacturer & Lot Number \\
\hline \multirow{2}{*}{1.} & \multirow{2}{*}{$\mathrm{MC}$} & Metal & $\begin{array}{l}\text { Starbond easy powder } \\
30\end{array}$ & $\begin{array}{c}\text { Scheftner dental } \\
\text { alloys, } \\
\text { S\&S Scheftner } \\
\text { GmbH, Germany }\end{array}$ & 0223060919 \\
\hline & & Ceramic & $\begin{array}{l}\text { IPS InLine } \\
\text { Dentin }\end{array}$ & $\begin{array}{l}\text { Ivoclar Vivadent } \\
\text { AG Schaan, } \\
\text { Principality of } \\
\text { Liechtenstein }\end{array}$ & $\begin{array}{c}\mathrm{A} 1=\mathrm{W} 39158 ; \\
\mathrm{B} 1=\mathrm{W} 40241 ; \\
\mathrm{C} 1=\mathrm{R} 71757\end{array}$ \\
\hline 2. & Emax-P & $\begin{array}{l}\text { Pressable } \\
\text { ceramic }\end{array}$ & $\begin{array}{l}\text { IPS e.max } \\
\text { Press }\end{array}$ & $\begin{array}{l}\text { Ivoclar Vivadent } \\
\text { AG Schaan, } \\
\text { Principality of } \\
\text { Liechtenstein }\end{array}$ & $\begin{array}{l}\mathrm{A} 1=\mathrm{Y} 05769 \\
\mathrm{~B} 1=\mathrm{Y} 44299 \\
\mathrm{C} 1=605274\end{array}$ \\
\hline \multirow{2}{*}{3.} & \multirow{2}{*}{ Emax-L } & Pressable & $\begin{array}{l}\text { IPS e.max } \\
\text { Press }\end{array}$ & $\begin{array}{c}\text { Ivoclar Vivadent } \\
\text { AG Schaan, } \\
\text { Principality of } \\
\text { Liechtenstein }\end{array}$ & $\begin{array}{l}\mathrm{A} 1=\mathrm{Y} 05769 \\
\mathrm{~B} 1=\mathrm{Y} 44299 \\
\mathrm{C} 1=605274\end{array}$ \\
\hline & & $\begin{array}{l}\text { Ceramic } \\
\text { layer }\end{array}$ & $\begin{array}{l}\text { IPS InLine } \\
\text { Dentin }\end{array}$ & $\begin{array}{l}\text { Ivoclar Vivadent } \\
\text { AG Schaan, } \\
\text { Principality of } \\
\text { Liechtenstein }\end{array}$ & $\begin{array}{l}\mathrm{A} 1=\mathrm{W} 39158 ; \\
\mathrm{B} 1=\mathrm{W} 40241 ; \\
\mathrm{C} 1=\mathrm{R} 71757\end{array}$ \\
\hline \multirow[b]{2}{*}{4.} & \multirow[b]{2}{*}{$\mathrm{Zr}-\mathrm{L}$} & $\begin{array}{l}\text { Zirconia } \\
\text { core }\end{array}$ & $\begin{array}{l}\text { ZI, LT, Zolid * } \\
\text { CAD/CAM } \\
\text { material }\end{array}$ & $\begin{array}{l}\text { Amann Girrbach, } \\
\text { Koblach, Austria }\end{array}$ & 1905001 \\
\hline & & $\begin{array}{l}\text { Layering } \\
\text { ceramic }\end{array}$ & $\begin{array}{l}\text { IPS Inline } \\
\text { Dentin }\end{array}$ & $\begin{array}{l}\text { Ivoclar Vivadent } \\
\text { AG Schaan, } \\
\text { Principality of } \\
\text { Liechtenstein }\end{array}$ & $\begin{array}{l}\mathrm{A} 1=\mathrm{W} 39158 ; \\
\mathrm{B} 1=\mathrm{W} 40241 ; \\
\mathrm{C} 1=\mathrm{R} 71757\end{array}$ \\
\hline \multirow[b]{2}{*}{5.} & \multirow[b]{2}{*}{$\mathrm{Zr}-\mathrm{M}$} & $\begin{array}{l}\text { Zirconia } \\
\text { block }\end{array}$ & $\begin{array}{c}\text { Zolid gen-x } \\
{ }^{*} \text { CAD/CAM material }\end{array}$ & $\begin{array}{l}\text { Amann Girrbach, } \\
\text { Koblach, Austria }\end{array}$ & 1905001 \\
\hline & & $\begin{array}{l}\text { Frame } \\
\text { shade }\end{array}$ & Dying liquid & $\begin{array}{l}\text { 3M ESPE, MN } \\
55,144 \text { USA }\end{array}$ & $\begin{array}{l}\mathrm{A} 1=68346 \\
\mathrm{~B} 1=68574 \\
\mathrm{C} 1=68579\end{array}$ \\
\hline
\end{tabular}

* Computer-aided design and computer-aided manufacturing (CAD/CAM).

\subsection{Specimen Preparation}

The disc shaped specimens from all the test groups were prepared with standardized dimensions of $10 \mathrm{~mm}$ diameter and $1.5 \mathrm{~mm}$ thickness and in line with the manufacturer's recommendations and instructions. For standardization of dimensions all the specimens, digitalized designing was carried out using 3D software (3D Builder, Microsoft Corporation, Washington, WA, USA). For the MC specimens, the non-precious, cobalt chromium alloy (Starbond Easy Powder 30, S\&S Scheftner GmbH, Dekan-Laist-Straße 52, D-55129 Mainz, Germany) was printed by 3D printer (MYSINT 100 Dual laser, SISMA S.p.A., Vicenza, Italia) and followed by ceramic application (IPS InLine Dentin, Ivoclar-Vivadent, AG Schaan, Principality of Liechtenstein). For the Emax-P ceramic specimens, wax up were fabricated followed by ceramic press (IPS e.max Press, Ivoclar Vivadent AG Schaan, Principality of Liechtenstein). For the Emax-L specimens, the pressed core (IPS e.max Press, Ivoclar Vivadent AG Schaan, Principality of Liechtenstein) was further layered with ceramic (IPS InLine Dentin, Ivoclar-Vivadent, AG Schaan, Principality of Liechtenstein). Core for Zr-L 
was fabricated (ZI, LT, Zolid all options zirconia, Amann Girrbach AG, Herrschaftswiesen 16842 Koblach, Austria) using computer-aided design and computer-aided manufacturing (CAD/CAM) and ceramic layer (IPS InLine Dentin, Ivoclar-Vivadent, AG Schaan, Principality of Liechtenstein) was applied afterwards. The Zr-M specimens (Zolid gen-x, Zolid all options zirconia, Amann Girrbach AG, Herrschaftswiesen 16842 Koblach, Austria) were milled (ceramill ${ }^{\circledR}$ motion 2, Amann Girrbach AG, Herrschaftswiesen 16842 Koblach, Austria) only. Glazing of all the specimens was accomplished at temperatures instructed by the manufacturer.

\subsection{Thermocycling of Specimens}

For simulating the intra oral environment, all the tested ceramics were stored in distilled water at $37^{\circ} \mathrm{C}$ for $24 \mathrm{~h}$. Thermocycling (Huber, SD Mechatronik Thermocycler, Germany) of all the specimens was carried out with following specifications: water temperature $=5-55^{\circ} \mathrm{C}$; cycles $=6000 ;$ dwell time $=30 \mathrm{~s}$; transfer time $=5 \mathrm{~s}$.

\subsection{Color Measurement of the Specimens}

For measuring the $L^{*} a^{*} b^{*}$ values of the specimens a spectrophotometer $\left(\right.$ LabScan $X E^{\circledR}$, HunterLab, Sunset Hills Road, Reston, VA, USA) was acquired. Each specimen was placed over the sensor of the spectrophotometer with two different black and while backgrounds, and three readings each for black and white background per specimen were recorded.

$$
\Delta \mathrm{E}=\left[\left(\Delta \mathrm{L}^{*}\right) 2+\left(\Delta \mathrm{a}^{*}\right) 2+\left(\Delta \mathrm{b}^{*}\right) 2\right]^{1 / 2}
$$

where $L^{*}=$ lightness, $a^{*}=$ green $(-a)$, and red $(+a)$ axis, and $b^{*}=$ blue $(-b)$, and yellow $(+b)$ axis [18].

The TP of each specimen was calculated from the color differences of the specimens obtained on white and black backgrounds. The following formula was used for calculating the TP:

$$
\mathrm{TP}=\left[\left(\mathrm{L}^{*} \mathrm{~B}-\mathrm{L}^{*} \mathrm{~W}\right)^{2}+\left(\mathrm{a}^{*} \mathrm{~B}-\mathrm{a}^{*} \mathrm{~W}\right)^{2}+\left(\mathrm{b}^{*} \mathrm{~B}-\mathrm{b}^{*} \mathrm{~W}\right)^{2}\right]^{1 / 2}
$$

The TP ranges from 0 to 100, with a high TP value indicating more translucency of the tested specimen. $\mathrm{L}^{*}$ stands for lightness, $\mathrm{a}^{*}$ for red-green axis, and $\mathrm{b}^{*}$ for yellow-blue axis. B: color coordinates over the black background, W: over the white background [19].

\subsection{Statistical Analysis}

All the data was tabulated and analyzed by statistical package for social sciences (SPSS; Version 23; SPSS Inc., Chicago, IL, USA). Descriptive stats for mean $L^{*} a^{*} b^{*}$ values, calculation of $\triangle \mathrm{E}$ and TP from the $\mathrm{L}^{*} \mathrm{a}^{*} \mathrm{~b}^{*}$ values were recorded and tabulated for the five tested ceramic materials. The formal analysis was carried out for comparing the mean values of $\triangle \mathrm{E}$ and TP ( $95 \% \mathrm{CIs}$ ) of all the five groups using one-way analysis of variance (ANOVA) and Tukey's multiple comparisons tests at probability of $\alpha<0.05$.

\section{Results}

Descriptive statistics (mean and standard deviation) of $\mathrm{L}^{*} \mathrm{a}^{*} \mathrm{~b}^{*}$ values recorded with a spectrophotometer for the five tested materials $(N=165)$ are presented in Table 2 . The lightness value indicator $L^{*}$ was lowest $(54.66 \pm 01.64)$ and highest $(79.87 \pm 0.18)$ for the groups Emax-P in shade $\mathrm{C} 1$ and $\mathrm{Zr}-\mathrm{L}$ in shade A1, respectively. The redness-greenness indicator $\mathrm{a}^{*}$ showed the lowest $(-2.20 \pm 0.31)$ and highest $(1.27 \pm 0.27)$ value for groups $\mathrm{Zr}-\mathrm{M}$ in shade A1 and MC in shade A1, respectively. The yellowness-blueness of the color indicator $b^{*}$ showed the lowest $(0.80 \pm 0.81)$ and highest $(14.31 \pm 1.02$.) value for groups $\mathrm{Zr}-\mathrm{M}$ in shade $\mathrm{A} 1$ and $\mathrm{MC}$ in shade $\mathrm{C} 1$, respectively. The variations in the $\mathrm{L}^{*} \mathrm{a}^{*} \mathrm{~b}^{*}$ values of the five tested ceramic materials are also presented in the spectral plots of the spectrophotometer (Figure 1). 
Table 2. Descriptive statistics of the mean (standard deviation) of $L^{*} a^{*} b^{*}$ values recorded with a spectrophotometer for the five tested materials $(N=165)$.

\begin{tabular}{|c|c|c|c|c|c|c|c|c|c|}
\hline \multirow{2}{*}{ Ceramic } & \multicolumn{3}{|c|}{ A1 } & \multicolumn{3}{|c|}{ B1 } & \multicolumn{3}{|c|}{$\mathrm{C} 1$} \\
\hline & $\mathbf{L}^{*}$ & $a^{*}$ & $\mathbf{b}^{*}$ & $\mathbf{L}^{*}$ & $a^{*}$ & $\mathbf{b}^{*}$ & $\mathbf{L}^{*}$ & $a^{*}$ & $\mathbf{b}^{*}$ \\
\hline $\mathrm{MC}(n=33)$ & $\begin{array}{l}67.90 \\
(1.27)\end{array}$ & $\begin{array}{c}1.27 \\
(0.27)\end{array}$ & $\begin{array}{l}12.89 \\
(0.58)\end{array}$ & $\begin{array}{l}75.92 \\
(0.74)\end{array}$ & $-46(0.15)$ & $\begin{array}{l}11.93 \\
(0.38)\end{array}$ & $\begin{array}{l}72.56 \\
(0.59)\end{array}$ & $42(0.46)$ & $\begin{array}{l}14.31 \\
(1.02)\end{array}$ \\
\hline Emax-P $(n=33)$ & $\begin{array}{l}68.13 \\
(0.46)\end{array}$ & $\begin{array}{l}-1.24 \\
(0.09)\end{array}$ & $4.75(0.17)$ & $\begin{array}{c}0.62 .00 \\
(1.15)\end{array}$ & $\begin{array}{l}-1.49 \\
(0.22)\end{array}$ & $6.84(1.11)$ & $\begin{array}{l}54.66 \\
(1.64)\end{array}$ & $-72(0.32)$ & $6.65(1.46)$ \\
\hline Emax-L $(n=33)$ & $\begin{array}{l}64.45 \\
(1.07) \\
\end{array}$ & $\begin{array}{l}-1.87 \\
(0.18)\end{array}$ & $6.16(1.19)$ & $\begin{array}{l}61.82 \\
(1.42) \\
\end{array}$ & $\begin{array}{l}-1.18 \\
(0.30)\end{array}$ & $5.90(1.16)$ & $\begin{array}{l}60.69 \\
(1.31) \\
\end{array}$ & $-75(0.26)$ & 8.29 (1.12) \\
\hline $\mathrm{Zr}-\mathrm{L}(n=33)$ & $\begin{array}{l}79.87 \\
(0.18)\end{array}$ & $\begin{array}{l}-2.20 \\
(0.09)\end{array}$ & $6.68(0.39)$ & $\begin{array}{l}65.55 \\
(1.35)\end{array}$ & $-54(0.34)$ & $8.75(1.06)$ & $\begin{array}{l}64.12 \\
(0.83)\end{array}$ & $-34(0.22)$ & $9.73(0.69)$ \\
\hline $\mathrm{Zr}-\mathrm{M}(n=33)$ & $\begin{array}{c}62.92 \\
(1.28)\end{array}$ & $\begin{array}{l}-2.20 \\
(0.31)\end{array}$ & $80(0.81)$ & $\begin{array}{l}70.65 \\
(0.54)\end{array}$ & $\begin{array}{l}-1.01 \\
(0.31)\end{array}$ & $9.34(0.90)$ & $\begin{array}{l}68.68 \\
(0.44)\end{array}$ & $-90(0.37)$ & $\begin{array}{l}11.18 \\
(0.81)\end{array}$ \\
\hline
\end{tabular}
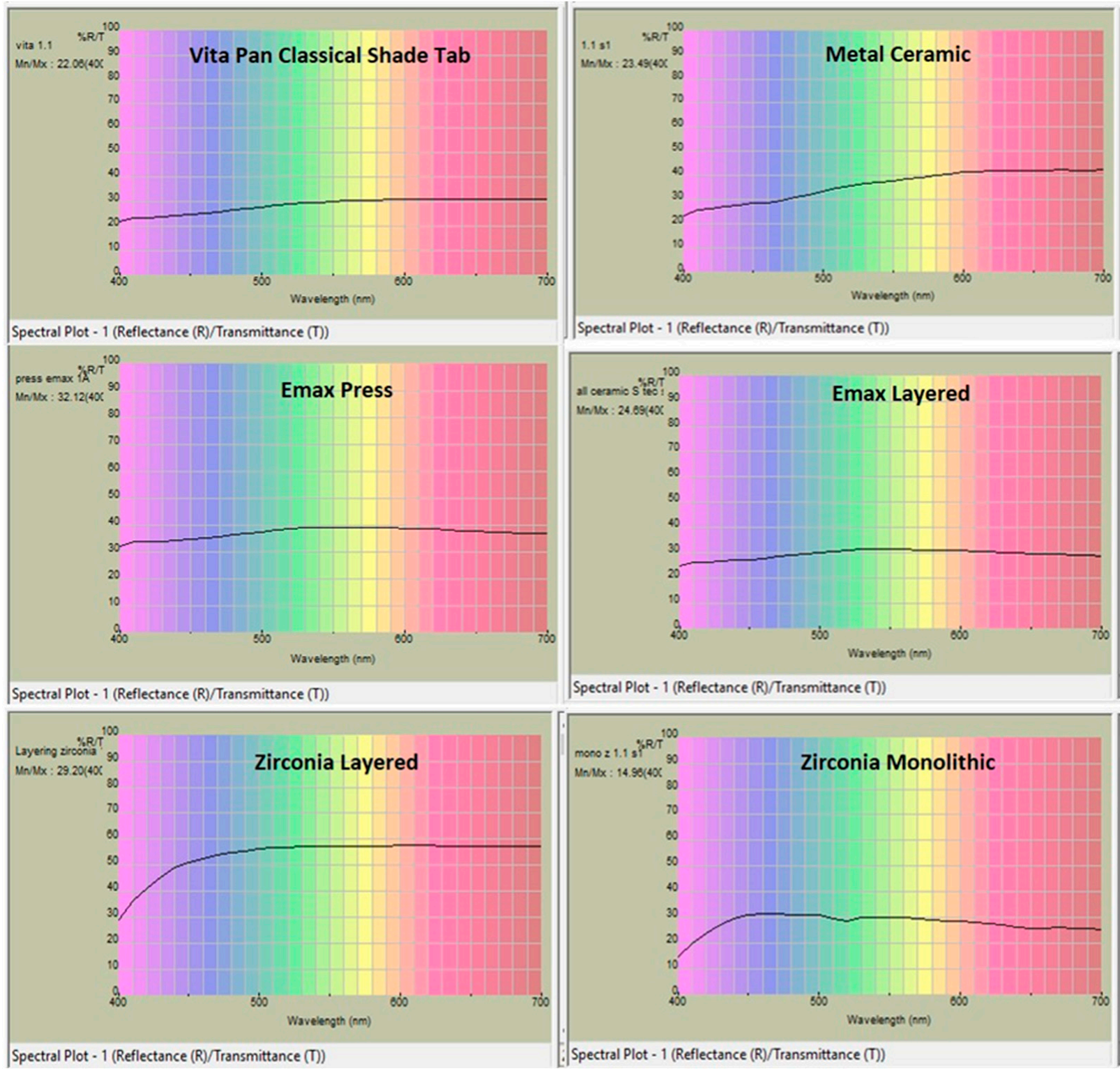

Figure 1. Spectral plot showing the $L^{*} a^{*} b^{*}$ values of the five tested ceramic materials and vita-pan shade tab, obtained from the spectrophotometer. 
The calculated mean $\Delta \mathrm{E}$ values for each respective test group are described in Table 3 . Statistically significant differences $(p=0.000)$ were found between the tested groups for the three shades. This confirms the existence of variations between the shades of different brands of ceramics. The highest $\Delta \mathrm{E}$ values in shade A1 were found for the Zr-L group $(80.18+0.20)$ and lowest for the Zr-M group $(62.97+1.28)$. With respect to shade B1, the highest $\triangle \mathrm{E}$ values were noted for the $\mathrm{MC}(76.85+78)$ group and lowest for the Emax-L $(62.13+1.49)$ group. While for the shade $\mathrm{C} 1$, the highest $\triangle \mathrm{E}$ values were found for $\mathrm{MC}$ group $(73.96+67)$ and lowest for the Emax-P group $(55.09+1.76)$. Multiple comparisons with Tukey's test revealed significant differences between the mean $\Delta \mathrm{E}$ values for test groups for all the three shades (A1, B1 and C1) except between MC and Emax-P ( $p=0.343)$ for shade A1 and Emax-P and Emax-L $(p=0.966)$ for shade B1.

Table 3. Mean and standard deviation of the delta $\mathrm{E}(\Delta \mathrm{E})$ of the tested ceramic materials $(N=165)$.

\begin{tabular}{|c|c|c|c|c|c|c|}
\hline \multirow{2}{*}{ Shade } & \multirow{2}{*}{$\begin{array}{c}\text { Ceramic } \\
(n=11 / \text { Group })\end{array}$} & \multirow{2}{*}{ Mean } & \multirow{2}{*}{$\begin{array}{c}\text { Std. } \\
\text { Deviation }\end{array}$} & \multicolumn{2}{|c|}{$\begin{array}{c}95 \% \text { Confidence Interval } \\
\text { for Mean }\end{array}$} & \multirow{2}{*}{$\begin{array}{l}\text { ANOVA } \\
p \text {-Value }\end{array}$} \\
\hline & & & & $\begin{array}{l}\text { Lower } \\
\text { Bound }\end{array}$ & $\begin{array}{l}\text { Upper } \\
\text { Bound }\end{array}$ & \\
\hline \multirow{5}{*}{ A1 } & $\mathrm{MC}$ & 69.12 & 1.34 & 68.22 & 70.03 & \multirow{5}{*}{0.000} \\
\hline & Emax-P & 68.30 & 0.46 & 67.99 & 68.62 & \\
\hline & Emax-L & 64.78 & 1.13 & 64.02 & 65.55 & \\
\hline & $\mathrm{Zr}-\mathrm{L}$ & 80.18 & 0.20 & 80.04 & 80.32 & \\
\hline & $\mathrm{Zr}-\mathrm{M}$ & 62.97 & 1.28 & 62.10 & 63.83 & \\
\hline \multirow{5}{*}{ B1 } & $\mathrm{MC}$ & 76.85 & 0.78 & 76.32 & 77.38 & \multirow{5}{*}{0.000} \\
\hline & Emax-P & 62.40 & 1.26 & 61.55 & 63.25 & \\
\hline & Emax-L & 62.13 & 1.49 & 61.12 & 63.13 & \\
\hline & $\mathrm{Zr}-\mathrm{L}$ & 66.15 & 1.28 & 65.28 & 67.01 & \\
\hline & $\mathrm{Zr}-\mathrm{M}$ & 71.28 & 0.60 & 70.87 & 71.69 & \\
\hline \multirow{5}{*}{$\mathrm{C} 1$} & $\mathrm{MC}$ & 73.96 & 0.67 & 73.51 & 74.42 & \multirow{5}{*}{0.000} \\
\hline & Emax-P & 55.09 & 1.76 & 53.90 & 56.27 & \\
\hline & Emax-L & 61.26 & 1.42 & 60.30 & 62.22 & \\
\hline & $\mathrm{Zr}-\mathrm{L}$ & 64.86 & 0.78 & 64.33 & 65.39 & \\
\hline & Zr-M & 69.59 & 0.41 & 69.31 & 69.87 & \\
\hline
\end{tabular}

The TP values for the test groups are elaborated in Table 4. Statistically significant differences $(p<0.05)$ were noted for the test groups, for the three shades and this confirmed the existence of translucency variations between various brands of ceramics. The highest TP values in shade A1 were found for the Emax-L group $(2.99+1.64)$ and lowest for the Zr-L group $(0.35+0.16)$. With respect to shade B1, the highest TP values were noted for the Emax-P $(3.50+1.74)$ group and lowest for the MC $(0.57+0.40)$ group. While for the shade $\mathrm{C} 1$, the highest TP values were found for the Emax-P group $(4.46+2.42)$ and lowest for the MC group $(0.58+0.48)$.

For comparisons with the vita-pan classical shade guide, $\Delta \mathrm{E}$ and $\mathrm{TP}$ values were calculated from the $\mathrm{L}^{*} \mathrm{a}^{*} \mathrm{~b}^{*}$ values recorded for the shade tab A1, B1, and C1 (Table 5). Statistically significant differences $(p<0.05)$ were found between the $\Delta \mathrm{E}$ values of the vita shade tab and the tested ceramic groups, except for the Exam-P group of shade $C 1$ $(p=0.245)$. For the TP, the majority of the differences between the vita shade tab and tested ceramic groups were non-significant (Table 6). 
Table 4. Mean and standard deviation of the translucency parameter (TP) of the tested ceramic materials $(N=165)$.

\begin{tabular}{|c|c|c|c|c|c|c|}
\hline \multirow{2}{*}{ Shade } & \multirow{2}{*}{$\begin{array}{l}\text { Ceramic } \\
(n=11 / \text { Group })\end{array}$} & \multirow{2}{*}{ Mean } & \multirow{2}{*}{$\begin{array}{c}\text { Std. } \\
\text { Deviation }\end{array}$} & \multicolumn{2}{|c|}{$\begin{array}{c}95 \% \text { Confidence Interval } \\
\text { for Mean }\end{array}$} & \multirow{2}{*}{$\begin{array}{l}\text { ANOVA } \\
p \text {-Value }\end{array}$} \\
\hline & & & & $\begin{array}{l}\text { Lower } \\
\text { Bound }\end{array}$ & $\begin{array}{l}\text { Upper } \\
\text { Bound }\end{array}$ & \\
\hline \multirow{5}{*}{ A1 } & $\mathrm{MC}$ & 0.80 & 0.58 & 0.41 & 1.19 & \multirow{5}{*}{0.000} \\
\hline & Emax-P & 0.54 & 0.26 & 0.36 & 0.72 & \\
\hline & Emax-L & 2.99 & 1.64 & 1.88 & 4.10 & \\
\hline & $\mathrm{Zr}-\mathrm{L}$ & 0.35 & 0.16 & 0.23 & 0.46 & \\
\hline & Zr-M & 2.18 & 1.16 & 1.39 & 2.97 & \\
\hline \multirow{5}{*}{ B1 } & $\mathrm{MC}$ & 0.57 & 0.40 & 0.29 & 0.85 & \multirow{5}{*}{0.002} \\
\hline & Emax-P & 3.50 & 1.74 & 2.33 & 4.68 & \\
\hline & Emax-L & 2.85 & 1.47 & 1.86 & 3.84 & \\
\hline & Zr-L & 1.16 & 0.97 & 1.50 & 2.81 & \\
\hline & $\mathrm{Zr}-\mathrm{M}$ & 1.51 & 0.98 & 0.85 & 2.18 & \\
\hline \multirow{5}{*}{$\mathrm{C} 1$} & $\mathrm{MC}$ & 0.58 & 0.45 & 0.27 & 0.88 & \multirow{5}{*}{0.000} \\
\hline & Emax-P & 4.46 & 2.42 & 2.83 & 6.09 & \\
\hline & Emax-L & 2.46 & 1.36 & 1.54 & 3.38 & \\
\hline & $\mathrm{Zr}-\mathrm{L}$ & 1.28 & 0.58 & 1.08 & 1.86 & \\
\hline & $\mathrm{Zr}-\mathrm{M}$ & 1.47 & 0.54 & 00.91 & 1.64 & \\
\hline
\end{tabular}

Table 5. Mean differences and multiple comparisons of the delta $\mathrm{E}(\Delta \mathrm{E})$ values with the $\Delta \mathrm{E}$ of vita shade guide tab.

\begin{tabular}{|c|c|c|c|c|c|}
\hline \multirow{2}{*}{$\begin{array}{c}\text { Vita Shade } \\
\text { Tab }\end{array}$} & \multirow[b]{2}{*}{ Ceramics } & \multirow{2}{*}{$\begin{array}{c}\text { Mean } \\
\text { Differences }\end{array}$} & \multirow{2}{*}{ Significance } & \multicolumn{2}{|c|}{ 95\% Confidence Interval } \\
\hline & & & & $\begin{array}{l}\text { Lower } \\
\text { Bound }\end{array}$ & $\begin{array}{l}\text { Upper } \\
\text { Bound }\end{array}$ \\
\hline \multirow{5}{*}{ A1 } & $\mathrm{MC}$ & $-8.44572 *$ & 0.000 & -9.6422 & -7.2493 \\
\hline & Emax-P & $-7.62453 *$ & 0.000 & -8.8210 & -6.4281 \\
\hline & Emax-L & $-4.10439 *$ & 0.000 & -5.3008 & -2.9079 \\
\hline & $\mathrm{Zr}-\mathrm{L}$ & $-19.50069 *$ & 0.000 & -20.6971 & -18.3042 \\
\hline & $\mathrm{Zr}-\mathrm{M}$ & $-2.28638^{*}$ & 0.000 & -3.4828 & -1.0899 \\
\hline \multirow{5}{*}{ B1 } & $\mathrm{MC}$ & $-16.92167 *$ & 0.000 & -18.5426 & -15.3008 \\
\hline & Emax-P & $-2.47386^{*}$ & 0.000 & -4.0948 & -0.8529 \\
\hline & Emax-L & $-2.19756^{*}$ & 0.002 & -3.8185 & -0.5766 \\
\hline & $\mathrm{Zr}-\mathrm{L}$ & $-6.22041 *$ & 0.000 & -7.8413 & -4.5995 \\
\hline & $\mathrm{Zr}-\mathrm{M}$ & $-11.35240 *$ & 0.000 & -12.9733 & -9.7315 \\
\hline \multirow{5}{*}{$\mathrm{C} 1$} & $\mathrm{MC}$ & $-17.75168 *$ & 00.000 & -19.2432 & -16.2601 \\
\hline & Emax-P & 1.12433 & 0.245 & -0.3672 & 2.6159 \\
\hline & Emax-L & $-5.05308^{*}$ & 0.000 & -6.5446 & -3.5615 \\
\hline & $\mathrm{Zr}-\mathrm{L}$ & $-8.64927 *$ & 0.000 & -10.1408 & -7.1577 \\
\hline & $\mathrm{Zr}-\mathrm{M}$ & -13.38383 * & 0.000 & -14.8754 & -11.8923 \\
\hline
\end{tabular}


Table 6. Mean differences and multiple comparisons of the translucency parameter (TP) values with the TP of vita shade guide tab.

\begin{tabular}{|c|c|c|c|c|c|}
\hline \multirow{2}{*}{$\begin{array}{c}\text { Vita Shade } \\
\text { Tab }\end{array}$} & \multirow[b]{2}{*}{ Ceramics } & \multirow{2}{*}{$\begin{array}{c}\text { Mean } \\
\text { Differences }\end{array}$} & \multirow{2}{*}{ Significance } & \multicolumn{2}{|c|}{ 95\% Confidence Interval } \\
\hline & & & & $\begin{array}{l}\text { Lower } \\
\text { Bound }\end{array}$ & $\begin{array}{l}\text { Upper } \\
\text { Bound }\end{array}$ \\
\hline \multirow{5}{*}{ A1 } & $\mathrm{MC}$ & 0.57773 & 0.694 & -.5923 & 1.7478 \\
\hline & Emax-P & 0.83711 & 0.298 & -0.3329 & 2.0072 \\
\hline & Emax-L & $-1.60877^{*}$ & 0.002 & -2.7788 & -0.4387 \\
\hline & $\mathrm{Zr}-\mathrm{L}$ & 1.03615 & 0.111 & -0.1339 & 2.2062 \\
\hline & $\mathrm{Zr}-\mathrm{M}$ & -0.79908 & 0.349 & -1.9691 & 0.3710 \\
\hline \multirow{5}{*}{ B1 } & MC & 4.57018 * & 0.001 & 1.4156 & 7.7247 \\
\hline & Emax-P & 1.63513 & 0.649 & -1.5194 & 4.7897 \\
\hline & Emax-L & 2.28642 & 0.284 & -0.8681 & 5.4410 \\
\hline & $\mathrm{Zr}-\mathrm{L}$ & 2.98210 & 0.074 & -0.1724 & 6.1366 \\
\hline & Zr-M & $3.62593 *$ & 0.015 & 0.4714 & 6.7805 \\
\hline \multirow{5}{*}{$\mathrm{C} 1$} & $\mathrm{MC}$ & $2.43905^{*}$ & 0.000 & 0.8504 & 4.0277 \\
\hline & Emax-P & -1.44388 & 0.095 & -3.0325 & 0.1448 \\
\hline & Emax-L & 0.55333 & 0.908 & -1.0353 & 2.1420 \\
\hline & $\mathrm{Zr}-\mathrm{L}$ & 1.54552 & 0.061 & -0.0431 & 3.1342 \\
\hline & $\mathrm{Zr}-\mathrm{M}$ & $1.73525 *$ & 0.024 & 0.1466 & 3.3239 \\
\hline
\end{tabular}

* $p$-value was significant at $p<0.05$.

\section{Discussion}

In the present in vitro research, the variations in the shades of five commonly used and most esthetic ceramics used for restoring anterior teeth, was investigated by calculating and comparing their $\triangle \mathrm{E}$ and TP. For this purpose, CIE- $\mathrm{L}^{*} \mathrm{a}^{*} \mathrm{~b}^{*}$ color values, considered as the complete numerical legend of the shade, were acquired by using a spectrophotometer. The ambient light does not affect the reading of this machine as the amount of light is reflected from the specimens and is recorded over a full spectral wavelength [20]. This methodology is widely accepted, and a high level of agreement is observed in its use, confirming reliability for in vitro research studies related to color and shades in dental sciences [21,22]. These machines are not used commonly in clinical settings, as the equipment is complex, expensive, and requires expertise for measuring the shade of teeth in clinics $[23,24]$.

Ideally the different restorative materials available commercially should exhibit no difference in their shades [25]. The data of this study revealed significant variations in the shades of the five investigated and tested ceramic groups with regard to the total-colordifference, i.e., $\Delta \mathrm{E}$ and the translucency parameter, i.e., TP. Thus, the null hypothesis of similar shades of the investigated materials is rejected.

Shade matching of the teeth is the unperceivable presence, tolerance, and acceptance by the clinician dentists and their patients with respect to the existing shade difference between the natural tooth and artificial restoration [26]. Despite the recent advancement in color science, many unsolved issues present serious concerns. The biggest challenge is to fabricate an artificial restoration possessing the same optical characteristics as that of the natural tooth structure. From an optical point of view, the natural teeth are a combination of heterogeneous, fluorescent, polychromatic crystalline structure that consists of a sequence of factors presenting varied levels of opacity and translucency [20,21]. Due to these variations in the constitution of the natural teeth, the shade to be determined is by the combination of optical phenomena "reflection, transmission, dispersion, internal scattering and selective filtering" [27]. The association between these is due to the emission of the different wavelengths from different structural parts of the teeth, which confirms the metameric 
behavior of the complex tooth structure under different light sources [27]. In contrast, the artificial materials used for restoring the lost tooth structure are usually monochromatic, uniformly translucent, untextured, and viewed under ideal lighting conditions [28].

The total color difference or $\Delta \mathrm{E}$ is considered as a standardized tool for evaluation and comparison of color changes in color science [20-29]. With regard to human teeth, different researchers have reported the $\Delta \mathrm{E}$ values from 1 to 7 to be clinically perceivable $[27,28]$. However, most of the studies have consensus on value of $\Delta \mathrm{E}>2.75$ as the clinically detectable and unacceptable esthetically [20-31]. For the acceptability of the shade differences, if the $\Delta \mathrm{E}>2.75$ is considered to be unacceptable, then according to the results of this study significant variations were found between the $\Delta \mathrm{E}$ of the five tested ceramic groups with three different shades. The variations were not only observed between the $\Delta \mathrm{E}$ of the five tested materials, but also between the $\Delta \mathrm{E}$ of each of the tested materials with the $\Delta \mathrm{E}$ of vita-pan classical shade tabs. Only 4 out of the 15 comparisons with vita-pan classical shade guide, showed the $\Delta \mathrm{E}$ to be $<2.75$, with the highest mean difference of up to -19.50 and lowest mean difference of 1.12. These findings confirm the existence of shade variations between the different brands and types of dental ceramics based on their composition. The findings of this study are in line with similar research studies conducted with identical methodology, which also reported the variations in the $\Delta \mathrm{E}$ [20-31].

Evaluation and comparison of the TP values of the tested ceramics revealed significant variations, thus rejecting the null hypothesis of similar translucency. However, relatively more consistency was observed between the TP values, in comparison to the $\Delta \mathrm{E}$ values for the same test materials. Highest TP values were found for the e.max groups, followed by the $\mathrm{Zr}-\mathrm{M}, \mathrm{Zr}-\mathrm{L}$, and the lowest TP values for the MC group. The e.max is a "lithium disilicate glass ceramic" material, that has been specifically produced with similar translucency to the natural teeth, and possesses the optimal translucency expected from an esthetic point of view of an anterior restoration that should exactly look like the natural teeth $[32,33]$. The zirconia groups (monolithic and layered) both showed lower TP values than the e.max groups, with the Zr-M group showing higher TP than the Zr-L group. These findings are in harmony with the manufacturing companies claiming the enhanced translucency of these newly developed monolithic zirconia [32,33]. However, the light transmission through these zirconia is still significantly lower than the glass based ceramics. Though the exact architecture of the zirconia used is not available, due to its monochromatic structure, the contents are increased, thus producing more cubic structures that enhance the zirconia translucency, owing to optical-anisotropy [34,35]. The lowest TP values among the five tested ceramic groups were for the MC group. The low translucency because of the metal substructure in the MC group was evident from the findings of this study and is line with previously reported research studies [36].

There is a remarkable improvement in the structure and composition of the dental ceramics during the last few decades, which has revolutionized the dental ceramics from an esthetic point of view. Today, the dentists have a number of options to select from mechanical, structural, biological, cost, and esthetic perspectives of dental ceramics while treating their patients [37]. There is no doubt that ceramics offer the best possible treatment options for the indirect restorations in the anterior high esthetic zone of the mouth. However, with the multiple options available for the dentists to choose from, it becomes very difficult to select the relevant ceramic material in terms of reproducing and matching the shade of adjacent teeth exactly [4]. This is critical because the dentist has to select the shade of the patient's teeth in the clinic and communicate it to the dental ceramic technologist for the reproduction of the same shade in the dental laboratory. The complex optical behavior of the natural teeth due to structural variations is a challenge for the dentist to deal with. The shade of the natural teeth even varies within the same teeth [26]. Thus, the optical phenomena of the dental ceramics play a vital role during the selection of the restorative materials for the teeth. Ceramic restorations type, composition, core, shade, layering ceramic, staining, and level of translucency are the main elements to be considered for providing the ideal aesthetics [38]. 
The interpretation of the present findings must be made with caution due to some limitations. All the specimens for each of the investigated group materials were prepared and fabricated by one trained ceramic technician and verified for the dimensions by the principal author. Every attempt was made to ensure the standardization of the specimen, however, chances of human error during the specimen preparation cannot be ruled out. An experienced technician in the laboratory recorded the spectrophotometric readings and it is almost impossible to produce the actual clinical setting with the current in vitro design. The differences in TP can further be associated to thickness of the specimens, sintering process, the different values of the white and black background, as well as the measuring devices. Future studies for crack formation investigation by microstructure observation and composition analysis such as X-ray fluorescence of the tested materials is suggested and recommended.

\section{Conclusions}

Significant variations in the total-color-difference $(\Delta \mathrm{E})$ and the translucency parameters (TP) were revealed for the tested ceramic groups. The tested ceramic materials showed clinically perceptible discrepancies between their shades according to the results. The ceramic materials may show more or less color differences, even if the materials are of the same shade. The shades of the various dental ceramics do not match with the shades of the vita-pan classical shade tabs, to which they are compared most often. Shade differences are present between different lots of ceramic materials from the same or different brands.

Author Contributions: Conceptualization, S.R.H.; methodology, A.S.A.R., T.A.S., A.H.A., H.A.A.; software, S.R.H.; formal analysis, S.R.H.; investigation, A.S.A.R., T.A.S., A.H.A., H.A.A.; resources, S.O.B., A.S.A., M.A.; data curation, A.S.A.R., T.A.S., A.H.A., H.A.A.; writing-original draft preparation, S.R.H.; writing-review and editing, S.R.H.; supervision, S.R.H.; project administration, S.R.H.; funding acquisition, S.O.B., A.S.A., M.A. All authors have read and agreed to the published version of the manuscript.

Funding: This research was funded by [Deanship of Scientific Research at King Saud University] grant number [RG-1441-336]. And the APC was funded by [Deanship of Scientific Research at King Saud University].

Institutional Review Board Statement: Not applicable.

Informed Consent Statement: Not applicable.

Data Availability Statement: The data is available on request from the corresponding author.

Conflicts of Interest: The authors declare no conflict of interest.

\section{References}

1. Shenoy, A.; Shenoy, N. Dental ceramics: An update. J. Conserv. Dent. 2010, 13, 195-203. [CrossRef] [PubMed]

2. Zhang, Y.; Kelly, J.R. Dental Ceramics for Restoration and Metal Veneering. Dent. Clin. N. Am. 2017, 61, 797-819. [CrossRef]

3. Sikri, V.K. Color: Implications in dentistry. J. Conserv. Dent. 2010, 13, 249-255. [CrossRef]

4. Fondriest, J. Shade matching in restorative dentistry: The science and strategies. J. Prosthet. Dent. 2004, 91, 553. [CrossRef]

5. Nohl, F.S.A.; Steele, J.G.; Wassell, R.W. Crowns and other extra-coronal restorations: Aesthetic control. Br. Dent. J. 2002, 192, 443-450. [CrossRef] [PubMed]

6. Chu, S.J.; Trushkowsky, R.D.; Paravina, R.D. Dental color matching instruments and systems. Review of clinical and research aspects. J. Dent. 2010, 38, e2-e16. [CrossRef]

7. Ahmad, S.; Habib, S.; Azad, A. Scientific and artistic principles of tooth shade selection: A review. Pak. Oral Dent. J. 2011, 31, 222-226.

8. Judeh, A.; Al-Wahadni, A. A comparison between conventional visual and spectrophotometric methods for shade selection. Quintessence Int. 2009, 40, e69-e79.

9. Alomari, M.; Chadwick, R.G. Factors influencing the shade matching performance of dentists and dental technicians when using two different shade guides. Br. Dent. J. 2011, 211, E23. [CrossRef] [PubMed]

10. Da Silva, L.H.; De Lima, E.; Miranda, R.B.D.P.; Favero, S.S.; Lohbauer, U.; Cesar, P.F. Dental ceramics: A review of new materials and processing methods. Braz. Oral Res. 2017, 31, e58. [CrossRef] 
11. Pop-Ciutrila, I.-S.; Ghinea, R.; Colosi, H.A.; Ruiz-López, J.; Perez, M.M.; Paravina, R.D.; Dudea, D. Color compatibility between dental structures and three different types of ceramic systems. BMC Oral Health 2021, 21, 75. [CrossRef]

12. Nemli, S.K.; Güngör, M.B.; Bağkur, M.; Bal, B.T.; Arıcı, Y.K. In vitro evaluation of color and translucency reproduction of maxillofacial prostheses using a computerized system. J. Adv. Prosthodont. 2018, 10, 422-429. [CrossRef]

13. Mokrzycki, W.; Tatol, M. Color difference Delta E-A survey. Mach. Graph. Vis. 2011, 20, 383-411.

14. Kim, J.-G.; Yu, B.; Lee, Y.-K. Correlations between Color Differences Based on Three Color-Difference Formulas Using Dental Shade Guide Tabs. J. Prosthodont. 2009, 18, 135-140. [CrossRef]

15. Jurišić, S.; Jurišić, G.; Zlatarić, D.K. In Vitro Evaluation and Comparison of the Translucency of Two Different All-Ceramic Systems. Acta Stomatol. Croat 2015, 49, 195-203. [CrossRef]

16. Ledić, K.; Majnarić, I.; Milardović, S.; Ortolan Špalj, S.; Štefančić, S.; Mehulić, K. Analysis of Translucency Parameter of Glass-Ceramics Fabricated by Different Techniques. Acta Stomatol. Croat. 2015, 49, 27-35. [CrossRef]

17. Erdfelder, E.; Faul, F.; Buchner, A. GPOWER: A general power analysis program. Behav. Res. Methods Instrum. Comput. 1996, 28, 1-11. [CrossRef]

18. AlJanobi, G.; Al-Sowygh, Z.H. The Effect of Thermocycling on the Translucency and Color Stability of Modified Glass Ceramic and Multilayer Zirconia Materials. Cureus 2020, 12, e6968. [CrossRef]

19. Kurt, M.; Bal, B.T. Effects of accelerated artificial aging on the translucency and color stability of monolithic ceramics with different surface treatments. J. Prosthet. Dent. 2019, 121, 712.e1-712.e8. [CrossRef] [PubMed]

20. Chitrarsu, V.K.; Chidambaranathan, A.S.; Balasubramaniam, M. Analysis of Shade Matching in Natural Dentitions Using Intraoral Digital Spectrophotometer in LED and Filtered LED Light Sources. J. Prosthodont. 2019, 28, e68-e73. [CrossRef]

21. Borse, S.; Chaware, S.H. Tooth shade analysis and selection in prosthodontics: A systematic review and meta-analysis. J. Indian Prosthodont. Soc. 2020, 20, 131. [CrossRef] [PubMed]

22. Alshiddi, I.F.; Richards, L.C. A comparison of conventional visual and spectrophotometric shade taking by trained and untrained dental students. Aust. Dent. J. 2015, 60, 176-181. [CrossRef] [PubMed]

23. Moodley, D.; Patel, N.; Moodley, T.; Ranchod, H. Comparison of colour differences in visual versus spectrophotometric shade matching. S. Afr. Dent. J. 2015, 70, 402-407.

24. Patankar, A.H.; Miyajiwala, J.S.; Kheur, M.G.; Lakha, T.A. Comparison of photographic and conventional methods for tooth shade selection: A clinical evaluation. J. Indian Prosthodont. Soc. 2017, 17, 273-281. [CrossRef] [PubMed]

25. Barutcigil, Ç.; Harorli, O.T.; Yildiz, M.; Özcan, E.; Arslan, H.; Bayindir, F. The color differences of direct esthetic restorative materials after setting and compared with a shade guide. J. Am. Dent. Assoc. 2011, 142, 658-665. [CrossRef]

26. Çapa, N.; Malkondu, O.; Kazazoglu, E.; Çalikkocaoğlu, S. Evaluating factors that affect the shade-matching ability of dentists, dental staff members and laypeople. J. Am. Dent. Assoc. 2010, 141, 71-76. [CrossRef] [PubMed]

27. Fried, D.; Glena, R.E.; Featherstone, J.D.B.; Seka, W. Nature of light scattering in dental enamel and dentin at visible and near-infrared wavelengths. Appl. Opt. 1995, 34, 1278-1285. [CrossRef]

28. Zarone, F.; Di Mauro, M.I.; Ausiello, P.; Ruggiero, G.; Sorrentino, R. Current status on lithium disilicate and zirconia: A narrative review. BMC Oral Health 2019, 19, 134. [CrossRef]

29. Chang, J.-Y.; Chen, W.-C.; Huang, T.-K.; Wang, J.-C.; Fu, P.-S.; Chen, J.-H.; Hung, C.-C. Evaluating the accuracy of tooth color measurement by combining the Munsell color system and dental colorimeter. Kaohsiung J. Med. Sci. 2012, 28, 490-494. [CrossRef]

30. Shoul, M.A.; Shadman, N.; Kandi, S.G.; Ebrahimi, S.F. The minimum thickness of a multilayer porcelain restoration required for masking severe tooth discoloration. Dent. Res. J. 2015, 12, 562-568. [CrossRef]

31. Lindsey, D.T.; Wee, A.G. Perceptibility and acceptability of CIELAB color differences in computer-simulated teeth. J. Dent. 2007, 35, 593-599. [CrossRef] [PubMed]

32. Succaria, F.; Morgano, S.M. Prescribing a dental ceramic material: Zirconia vs lithium-disilicate. Saudi Dent. J. 2011, 23, 165-166. [CrossRef] [PubMed]

33. Wang, F.; Yu, T.; Chen, J. Biaxial flexural strength and translucent characteristics of dental lithium disilicate glass ceramics with different translucencies. J. Prosthodont. Res. 2020, 64, 71-77. [CrossRef] [PubMed]

34. Kim, H. Optical and Mechanical Properties of Highly Translucent Dental Zirconia. Materials 2020, 13, 3395. [CrossRef] [PubMed]

35. Zhang, Y. Making yttria-stabilized tetragonal zirconia translucent. Dent. Mater. 2014, 30, 1195-1203. [CrossRef] [PubMed]

36. Sravanthi, Y.; Ramani, Y.; Rathod, A.M.; Ram, S.M.; Turakhia, H. The Comparative Evaluation of the Translucency of Crowns Fabricated with Three Different All-Ceramic Materials: An in Vitro Study. J. Clin. Diagn. Res. 2015, 9, ZC30-ZC34. [CrossRef] [PubMed]

37. Butt, K.; Thanabalan, N.; Ayub, K.; Bourne, G. Demystifying Modern Dental Ceramics. Prim. Dent J. 2019, 8, 28-33. [CrossRef]

38. Volpato, C.; Philippi, A.; Petter, C.; Fredel, M. Ceramic Materials and Color in Dentistry; INTECH Open Access Publisher: London, UK, 2010. 